\title{
Protesters target European animal patents
}

Munich. A coalition of animal rights activists led by two British animal welfare groups is stepping up its campaign against animal patenting this week by formally opposing the granting by the European Patent Office (EPO) of a patent for the Harvard University Oncomouse. The opposition coincides with a pan-European campaign to prevent patenting of any animal or plant.

The British Union for Antivivisection and Compassion in World Farming are the forces behind a coalition of another 24 animal welfare groups in Europe. They believe that the granting of the patent last May contravenes a clause in the convention adopted in 1973 by the EPO's 16 signatories that prohibits patent for an invention whose exploitation may be "contrary to morality".

The opposition highlights the ambiguity of the convention's 'morality clause'. Written before the concept of transgenic animals was realized, it gives no helpful guidelines and leaves the definition of morality to the patent office.

The coalition disagrees with the EPO's interpretation, saying that engineering of animals designed to suffer is inherently immoral. It also points out that the patent covers the creation of transgenic animals never considered by the EPO.

In 1985, Harvard submitted an application for its Oncomouse to the EPO in $\mathrm{Mu}$ nich. Although a US patent was granted in 1988, the EPO threw out the application in July 1989 , quoting the morality clause. But Harvard won on appeal after the EPO Board of Appeals decided that morality should be assessed "mainly on a careful weighing up of the suffering of animals and possible risks to the environment on the one hand, and the invention's usefulness to mankind on the other".

But the coalition also argues that the claim for usefulness is exaggerated, saying that animal models have limited value for human diseases. It also disputes the claim

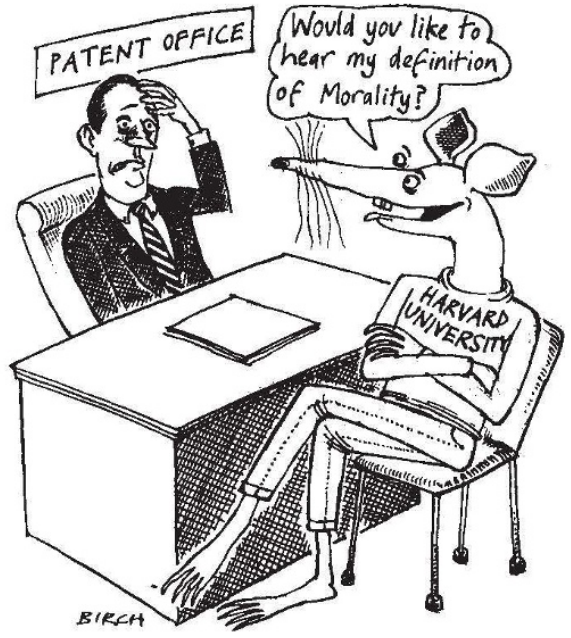

that fewer animals will be used, saying that because of the high background of spontaneous cancers, the increased sensitivity of the Oncomouse to carcinogens will be offset by the high background of spontaneous tumours.

Objections to any patent may be submitted for up to nine months after it is granted, in this case by 13 February. The coalition expects to be joined by many other protest groups, including Germany's Kein Patent auf Leben, another umbrella group representing 48 individual pressure groups.

The EPO may take a year to respond. Although the principle that animals are patentable has now been established, individual applications (and there are now more than 100 pending) are considered on a case-bycase basis. The EPO also says that the recent granting of three further US patents on transgenic mice (see story below) will not affect its decision.

Coinciding with this growing protest is a debate within the parliament of the
European Communities (EC) on amendments to a proposed EC directive, whose aim is to give each member state equal patent protection for biotechnology inventions. The amendments, now in the hands of the European Commission, give some protection to animals but, more importantly, attempt to define the term morality. A move by the parliament to ban animal patents was narrowly defeated (by a vote of 96-104) last November. The final decision rests with the EC's Council of Ministers.

If the directive is passed with amendments that help to clarify the meaning of morality, it is likely that the 1973 law will be altered to conform to such wording. All EC countries, as well as several others, are signatories, and it is important that there is no conflict in the laws of the two bodies. Any reduction in the EPO's ability to address ethical issues is likely to ease tensions, even if the controversy over patenting of life forms is not laid to rest.

Alison Abbott

\section{Ruling narrows US view of animal patents}

San Francisco. A decision by the US Patent and Trademark Office to grant patents on three transgenic mice opens the gates to more patents on animals but suggests the government may be taking a more narrow view of the issue.

On 29 December, the agency issued patents on a Harvard-developed mouse model for prostate enlargement, known as "Harvard II'; a mouse developed at Ohio University that produces human beta interferon, a natural protection against viral infections; and a mouse developed by GenPharm Inc. of Mountain View, California, that fails to develop mature T cells and would serve as a model for AIDS, rheumatoid arthritis and transplant rejection.

The only previous US patent on an animal was issued in 1988 for a mouse genetically engineered by Philip Leder and his colleagues at Harvard as a model for human cancers. That patent caused an uproar among animal-rights activists, environmentalists and some farmers, but a suit filed by animal activists against the patent office was not heard because the group could not demonstrate that any harm had been done. In addition, Congress has failed three times to enact a moratorium against patents on animals.

The length of time between the original "Harvard mouse" and last week's patents caused some to wonder whether the agency had adopted an unofficial moratorium. But Charles Warren, deputy director of the biotechnology patent examining group, says that the complexity of the claims was the primary reason for the delay in issuing the patents. Ohio University filed its application in September 1987, followed by GenPharm in December 1988 and Harvard in February 1989.

Paul Clark, a lawyer with Fish \& Richardson in Boston who prosecuted the Harvard II patent, said a major stumbling block had been a two-year argument over the breadth of the claim. Characterizing the agency's position as "retrenchment", Clark said government officials decided that genetic engineering on animals is unpredictable and that, therefore, a researcher could make claims only for those animal species on which the experiments had actually been done.

That policy differs from the agency's stance on the original Harvard mouse, which extends to alterations of the same gene in any mammal. Harvard II and the other new mouse patents apply to that species only. Future animal patents are likely to be similarly restricted, Clark predicted.

Warren said the patent office is considering 185 applications involving animals. At the agency's historical rate of allowance, only 50 or so are likely to be issued patents. Animals are being used as models for other human diseases as well as in research to improve the qualities of various farm animals. GenPharm, Genzyme Corporation of Cambridge, Massachusetts, and other companies are also genetically altering mammals such as mice, goats and cows to produce human proteins in their milk for therapeutic use.

Sally Lehrman 